\title{
Medicine and Travel
}

\section{So you want to climb Everest . . . ?}

\author{
R N VILLAR
}

Tibet is a long way from home and if it was not for Everest I would never have gone there.

Mount Everest, at over 29000 feet, must be the most frustrating mountain in the world. The first expedition to stand a man on the top, in 1953, was the 17 th such attempt on the summit, though these days, with modern equipment, a party has a $25 \%$ chance of success. Historically, it is a catalogue of disaster. Avalanche, exposure, and falls have killed as many climbers as there have been expeditions, and now, in 1984, the total stands at over 50 . I confess to being blissfully unaware of the odds when it was first put to me that I might accompany a party to "the big one" at a time to be subsequently arranged. Once I did realise the hazards my feelings hovered between total panic and professional puzzlement as to how you should organise the medical cover for a venture of such magnitude. Everest doctors had, it seemed, always formed an élite clique, possessing knowledge and skills not available to the ordinary run of the mill clinician such as myself. That was four years ago. Now, with a couple of high altitude expeditions under my belt, I too am an Everest doctor, having been tested both personally and medically to a degree that I would never have thought possible.

An expedition of 14 men is, by modern standards, enormous. Two of our number, Bronco and Brummy, had reached the summit in 1976, being forced by bad weather to bivouac overnight within a stone's throw of the top. The fact that they are still alive pays great credit to their determination and fortitude though frostbite claimed all their toes and, in Bronco's case, most of his fingers. Whose idea it was to return to Everest I do not know, but by 1980 , with Bronco firmly established as expedition leader, plans for a further British assault on the mountain were well under way. The route to be climbed would be the north face, a challenging choice, and one that would require an approach through Tibet rather than the more usual southerly routes that originate in Nepal. This was an opportunity too good to miss. We would be retracing the steps of such famous names as Mallory, Irvine, and Norton who, in the 1920s, made history by climbing above 28000 feet supported by little more than oxygen, tweed jackets, and quails' eggs.

\section{Four years' preparation}

Bronco and Brummy worked hard. For months, if not years, they planned, begged, borrowed, and cadged, slowly bringing together the team that would ultimately set out for Tibet. The climbers they found were of high calibre-if anyone could make it it would be them. Each man had made a significant personal or professional sacrifice to ensure his place on the trip. I had left a full

\footnotetext{
Department of Orthopaedic Surgery, Southampton General Hospital, Southampton, Hants SO9 4XY

R N VILLAR, BSC, FRCS, orthopaedic registrar
}

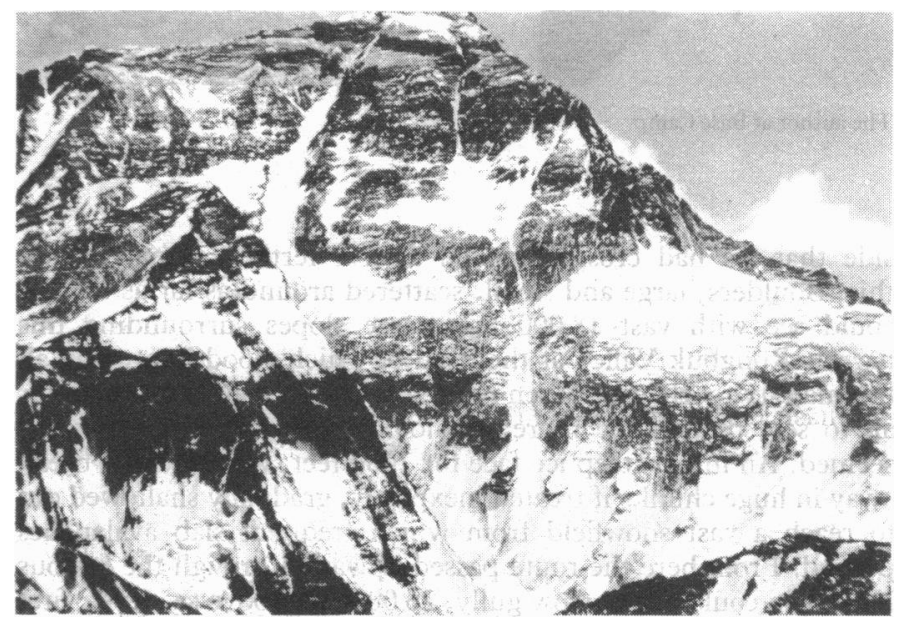

The North Face.

time Royal Army Medical Corps career to try for Everest so all I would return to would be the dole queue.

The medical side was my job. At the start I was a total novice and though I had worked with the various team members over several years, high altitude medicine was completely new to me. Still, I had four years in which to learn, and so armed with as many books on the subject as I could find and a good deal of advice from doctors experienced in such things, I set about teaching myself to climb. This, and a training expedition to Mount McKinley in Alaska, taught me that you cannot be an expedition doctor and climb as well for you will become so exhausted trying to keep yourself alive that you will have no time available for your patients. All my equipment I laboriously packed, tablet by tablet, six months before we were due to go. My wife, who by this stage had become quite carried away at the prospect of having a husband on Everest, arrived home from her surgery each night with another idea for an addition to the medical kit. It was thus with some relief that I closed the lid on the final box telling myself that if anything was missing it was not worth taking anyway.

It took us 10 days to reach the mountain on a route described by many authors far more literate than I. Mostly we travelled on the Friendship Highway in southern Tibet, 500 miles of lurching, bumping, dusty dirt track, crossing barren, windswept mountain passes above 15000 feet. We were 60 miles away when we first saw her, an evil black pyramid with a long plume of snow being continuously blown from the summit. It was unmistakably Everest, looking nothing like the photographs that I had seen. I admit to feeling an odd sensation in my epigastrium at that time, a feeling that I kept firmly to myself. The view that we had had was but a fleeting glimpse and at far too great a distance to pick out details, but it was enough to tell us that from tomorrow the good times were over and hard work soon to begin.

We arrived at base camp late one evening in early March. It surely must be the most desolate spot in the world. The country- 


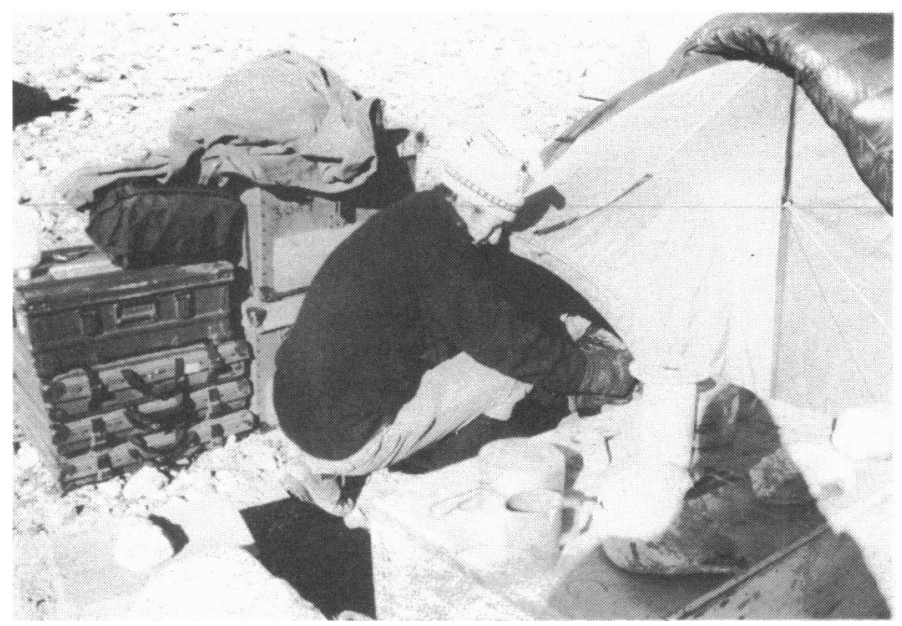

The author at Base Camp.

side that we had crossed looked almost fertile compared with this. Boulders, large and small, scattered around as far as the eye could see with vast 18000 foot scree slopes surrounding this narrow Rongbuk Valley at the head of which stood Everest in all her majesty, perhaps a dozen miles away. Our route was there for all to see, though the more you looked the more forbidding it seemed. An initial steep ice face for 2000 feet, which would break away in huge chunks if treated inexpertly, gradually shallowed out to reach a vast snowfield from which frequent slab avalanches poured. From here the route passed upwards through the famous Hornbein couloir, a narrow guily, 26000 feet above sea level, first used by an American, Dr Tom Hornbein, on a successful summit bid 20 years before. He had reported that the rock at this point had been so crumbly that he had feared for his life, deciding to descend by a different route than the one that he had used on the way up. Once above his couloir it is a mere 2000 feet to the top, though the temperature can be $-40^{\circ} \mathrm{C}$, the wind gusting 100 miles an hour and visibility negligible. We were not original. In 1980 the Japanese had used such a route, successfully, but lost one man on the way. For ourselves, it made no difference that the route had been climbed before. All we wanted was to reach the summit-we could only hope that Everest agreed.

For the first few days at a base camp there are always things for a doctor to do. Not everyone acclimatises at the same rate, headaches are frequent, dyspepsia common, and insomnia almost the rule. The Tibetan dust was playing havoc with our sinuses and for a while our little community sounded more like a tuberculosis ward than an expedition. I chuckled inwardly when one of the men developed housemaid's knee but, three days later when both he and the others were in fine fettle, dashing up the surrounding slopes to acclimatise, I began to feel superfluous. Indeed, I remember thinking that, with luck, my medical contribution to the expedition was over, because if I was required again it was likely to be in the case of an accident.

\section{Piece of heaven}

That first week I discovered my own perfect piece of heaven. The foothills of Everest, whether in Nepal or Tibet, are dotted with religious buildings, monuments, cairns, and shrines. Our base camp was beside the remains of the Rongbuk Monastery, a going concern for the 1920s expeditions which would stop to be blessed before starting to climb. The Chinese cultural revolution put an end to that, devastating all but a handful of monasteries though now, at moderate expense, the Chinese are rebuilding what they originally destroyed. My piece of heaven was just nearby. I had been out walking with Tony, one of our lead climbers, when we stumbled across it quite by accident. A tight, narrow, rocky gorge with vertical sides climbing 2000 feet into the air. In the bottom was a frozen, glacial stream, everything set solid, even the waterfalls. Tiny, abandoned houses were everywhere, obviously deserted in haste with shattered urns still in position by the fireplace. Tony was quite taken aback. So was I. From that moment on, whenever I needed to escape from the pressures of expedition life, I would visit the place to write, or to sit, or to think and now that I am home, of all my memories, that place is the most vivid.

By this time other expeditions had begun to arrive, a team from the United States and a small group from the Lake District. The Americans, as always, had come to do Everest in style. On a different route from ourselves, they had brought with them six doctors and enough research equipment to last a lifetime. I felt very humble as I crawled into my little ridge tent that had to double as both accommodation and medical storeroom, illuminated by one pathetic candle. There was no comparison with their superb, centrally heated, double skinned affair that would not have looked out of place at Cape Kennedy. My pride was restored when I asked to borrow a triangular bandage and, despite such technology, they were unable to oblige. Triangular bandages excepted, they could not have been more helpful and in exchange for providing guinea pigs for their portable electroencephalograph they were happy to be on standby should they ever be required.

Our chief load carrier, the yak, must be the most temperamental animal on earth, all horns and hair but with the intellect of a sheep. Their handlers are likewise a breed apart, permanent hypochondriacs, controlling their beasts by singing, whistling, and the occasional stone. Not for them a legally binding signed agreement, if their animals did not want to work that day then nothing could entice them to move. Once, in truly aggressive surgical fashion, I tried to force the issue by insisting that they carry a standard weight in a standard time. Much good it did me. Within seconds both yaks and handlers were on strike, disappearing out of sight down the valley and refusing to work for the rest of the trip. My status as a doctor plummeted and it was only after repeated bribes with cigarettes and Jamaican rum that they agreed to resume work at a speed to be determined by them. If the government finds it hard with our unions they ought to try yaks.

A month after our arrival only I and the camp manager were left in base camp. Our task, beyond creating chaos with the yaks, was to ensure a steady flow of supplies to the climbers in front. They were doing brilliantly, had negotiated a couple of fearsome crevasses, and surmounted the difficult ice wall that forms the first 2000 feet of the north face. Working at 22500 feet and only 500 feet short of our next camp, they would come down to an altitude of 20500 feet to sleep. When I visited them I remember commenting on how well they looked. At this altitude you can expect health to slowly deteriorate and I was expecting to find individuals in some disrepair. To my astonishment they were healthy, each man with a twinkle in his eye that you only see when he is responding to a challenge that he feels he can win. I returned to base camp feeling wonderfully exhilarated, proud to belong to a team that was so obviously doing well and glued myself to the radio twice daily to see how the frontrunners were doing.

\section{Catastrophe at 5 am}

It happened at five in the morning. A massive avalanche that destroyed our forward camp as the climbers slept in their tents. This was no ordinary snowslide. That night had seen terrible winds; even at base camp I had been up for hours battening down my tent to stop it blowing away. Enormous ice blocks, some the size of motor cars, tumbled off the mountain over a mile and a half away, gathering speed as they went, picking up the camp, and throwing it 500 yards down the glacier. Tony was killed outright. His partner Andy was crushed beneath large ice blocks, receiving a head injury that almost killed him, if he had but known. The other survivors were lucky, a cervical spine lesion and a case of frostbite were all that they could offer, but at this altitude such minor injuries were major problems indeed. With alarming rapidity my 
quiet medical existence had turned into total clinical chaos. My worst fears were confirmed. Tony was dead, such a good friend, too, but there was nothing that could be done for him now. We buried him where he lay, wrapped in our flag, and with a dignity that his family would welcome. The problem was now the survivors. Brummy's cervical spine and Graham's frostbite were no trouble. They were both conscious and mobile and, though I had no way of knowing if Brummy's neurological changes were indicative of an unstable fracture, he was at least capable of walking. No, the main worry was Andy. I was stuck with a semiconscious, immobile patient at almost 20000 feet. For a healthy man, base camp, and the road, was six hours' arduous walk away; the stretcher had been broken but the weather was good. Andy owes his life to his own strength and the help of his team mates who carried him down, semicomatose, on an undamaged crevasse ladder. It was four days from injury before we reached base camp during which time he had had a respiratory arrest, frequent cyanotic attacks, and inhalation of vomit. I cannot pretend that evacuations of that nature ever go smoothly, but he is alive, albeit battered, and will most likely climb again. From base camp he, and the other injured fellows, would have to return home, while the remainder of the team would stay and salvage what they could.

The journey home was an epic one. Our Tibetan driver became somewhat alarmed at the prospect of carrying three injured men, his concentration wavered, and our jeep ran off the road. We were not impressed and were fortunate not to damage ourselves further. For the next five days we jolted across the land, stopping at villages to beg $x$ ray facilities and being obliged to use machines so primitive that even now my gonads are humming with the quantity of radiation that they have probably received. It was not until we reached Hong Kong, nine days after injury, that an effective $x$ ray supported diagnosis was made.

I am home now and the expedition is over, for not only did we lose four good climbers but all our equipment as well. Despite the tragedy, I will have fond memories of Everest and my determination to succeed next time will be stronger than before. Tony is the reason, at least part of the reason, that I think that we would like to return. Often he would sit in our private little valley and philosophise on why he was there. I remember him saying, despite the challenge, that he wanted to reach home alive. He would not forgive us if we did not return and so, if you are going, I will come.

\title{
Six months on a slow boat to China
}

\author{
NICHOLAS HOLLIS
}

20 June-South China Sea. The ship lurched again and I rolled to the edge of my canvas bunk; not so far as to fall out, but enough to break the false security of the half sleep in which I was trying to escape our grim situation. We knew that if she rolled over a few more degrees the gear and ballast could shift and then she would keel right over and sink. It was raining steadily, and with the hatch covers down the atmosphere below was fetid from the crew's bodies, wet clothes, ropes, food, and things rotting in the bilges. For five days now we had been alternately running downwind and lying ahull during squalls that had ripped most of our sails to shreds. There was a threat of a typhoon, and as I lay below off watch my thoughts went back and I wondered about the chances of ending up as shark meat after all.

My thoughts had gone back six months to December, when I had been in the warmth and security of a London operating theatre. My surgical colleague had jokingly asked if I was interested in sailing on a mediaeval dhow from Oman to China and had added that it might be good fun if we didn't end up as shark meat. Within four weeks I had given up administering anaesthetics under the 40 watt English winter daylight and was looking after my new patients and shipmates in the dazzling brightness of Sri Lanka. Happily, the sharks ended up as meat for us and not the other way round.

\section{The dhow}

Sohar was a 97 foot boom dhow built in Oman the previous year. Superficially she looked much like many other large dhows; the crucial difference was that she had no engine and there were no bolts or nails used in her construction. Her timbers were fastened with 400 miles of coconut fibre rope, each plank being stitched to its fellow. It was a technique of construction used by Arabs in the eighth

Westminster Hospital, London SW1

NICHOLAS HOLLIS, FFARCS, locum senior registrar

Correspondence to: 3 Hamilton Drive, Melton Mowbray, Leicestershire, LE13 0QY. century, but from the time of the Portuguese it was neglected on larger vessels in favour of iron nails. It is said that the Arabs believed that there was a great magnet in the sea that would draw the nails out of a ship's timbers. The sewn part of the construction was one of the largest unknowns, but it turned out to be watertight as well as flexible. Perhaps surprisingly, a sewn ship had a much longer life than a nailed one, in which the nails have to be replaced every few years because of rusting.

\section{The crew}

Sohar was so named after a sea town in Oman which in the eighth to the tenth century was the centre of a large Omani seaborne empire extending from Zanzibar to China. The tales of Sindbad's voyages probably originate from yarns of seafarers of those times, and the town of Sohar was reputed to have been Sindbad's birthplace. It was to retrace the stories of the Sindbad legend along the spice trade route to China that Tim Severin, the project leader, built Sohar with generous support from the Omani government. Sohar left Oman in November 1980 with a crew of eight Omanis, a Baluchi cook, an Indian shipwright, and an assortment of 11 Europeans: Tim Severin the captain, marine biologists, a photographic team, and divers, but at that stage no doctor. The ship arrived in Sri Lanka-the Arabs' "Serendeeb" or serendipity-in January. The constant potential for serious injury with the heavy blocks and spars and a bone deep gash in the foot of Peter Dobbs, our diver, emphasised the need for a doctor on board before the longer and more arduous legs of the voyage.

I found myself in sharp contrast to the dark skinned and piratical looking crew dressed largely in loincloths. I think the Omanis had expected their new doctor to wear a white tropical uniform, keep his hands clean, and hold formal surgeries. It might have made the Omanis hold my medical skills in greater esteem if I had done so, for it was a surprise to them to see their doctor wearing a lungi and pulling on the ropes alongside them.

The Omanis were all good seafarers, most of them having a recent sailing heritage. Several had been on trips to Africa as boys before the dhow trade ceased. One, Juma, a man of indefinite age, was a 